\title{
Secretory tumors of the pituitary gland: a clinical biochemistry perspective
}

https://doi.org/10.1515/cclm-2018-0552

Received May 26, 2018; accepted July 16, 2018; previously published online August 18, 2018

Abstract: The pituitary gland is responsible for the production and/or secretion of various hormones that play a vital role in regulating endocrine function within the body. Secretory tumors of the anterior pituitary predominantly, pituitary adenomas, collectively account for $10 \%-25 \%$ of central nervous system tumors requiring surgical treatment. The most common secretory tumors are prolactinomas, which can be diagnosed by basal prolactin levels. Acromegaly can be diagnosed by basal insulin growth-like factor 1 levels and the failure of growth hormone (GH) to suppress during an oral glucose tolerance test. Cushing disease can be diagnosed by demonstrating hypercortisolemia evidenced by increased salivary cortisol levels in the evening, increased urine free cortisol excretion and failure of plasma cortisol to suppress following oral dexamethasone given overnight $(1.0 \mathrm{mg})$. We also discuss the diagnosis of the rarer thyroid-stimulating hormone and gonadotrophin secretory tumors. Morbidity is associated with tumor occurrence, clinical sequelae as well as the related medical, surgical and radiological management. This review focuses on the pathogenesis of secretory tumors of the anterior pituitary with emphasis on molecular mechanisms associated with tumorigenesis and the major role of the clinical chemistry laboratory in diagnosis and management of these tumors.

Keywords: acromegaly; adrenocorticotrophin (ACTH); anterior pituitary; clinical chemistry; Cushing disease; growth hormone (GH); prolactin; secretory tumors; thyroid-stimulating hormone (TSH).

*Corresponding author: Ishwarlal Jialal, MD, PhD, FRCPath, DABCC, Assistant Dean of Research, California North-State University, College of Medicine, Elk Grove, CA 95757, USA; and Director, Section of Clinical Chemistry, VA Medical Center, Sacramento, CA, USA, E-mail: ishwarlal.jialal@cnsu.edu

Verena Gounden and Yashna D. Rampursat: Department of Chemical Pathology, University of KwaZulu Natal and National Health Laboratory Services, Inkosi Albert Luthuli Central Hospital, Durban, South Africa
Abbreviations: ACTH, adrenocorticotrophin; ADH, antidiuretic hormone; AIP, aryl hydrocarbon receptor interacting protein; BIPSS, bilateral inferior petrosal sinus sampling; CC, carney complex; CNS, central nervous system; $\mathrm{CpG}$, cytosine linked to guanine nucleotide by a phosphodiester bond; CRH, corticotrophin-releasing hormone; DGSA, densely granulated somatotroph adenomas; EGF, epidermal growth factor; EGFR, epidermal growth factor receptor; FGF-B, fibroblast growth factor-B; FIPA, familial isolated pituitary adenoma; $\mathrm{FSH}$, follicularstimulating hormone; $\mathrm{GH}$, growth hormone; GHBP, $\mathrm{GH}$ binding protein; GHR, GH receptor; GHRH, growth hormone-releasing hormone; GnRH, gonadotrophin-releasing hormone; HNF-4 $\alpha$, hepatocyte nuclear factor $4 \alpha$; ICTP, carboxy-terminal cross linked telopeptide type 1 collagen; IGF-1, insulin-like growth factor 1; IPS, inferior petrosal sinus; LDDST, low dose dexamethasone suppression test; LH, luteinizing hormone; MCR2, melanocortin receptor 2; MEN-1 syndrome, multiple endocrine neoplasia type 1 syndrome; miRNAs, micro RNAs; mRNA, messenger RNA; ODST, overnight dexamethasone suppression test; PEG, polyethylene glycol; PKA, protein kinase A; POMC, pro-opiomelanocortin; $\mathrm{PRIH}$, prolactin release inhibiting hormone; PRKAR1A, protein kinase, cyclic AMP-dependent regulatory type $1 \alpha$; PRL, prolactin; PrRP, prolactinreleasing peptide; PTTG, pituitary tumor transforming gene; SGSA, sparsely granulated somatotroph adenomas; SHBG, sex hormone-binding globulin; T3, tri-iodothyronine; T4, thyroxine; TGF-B, tumor growth factor-B; THR, thyroid hormone resistance; TRH, thyrotropin releasing hormone; TSH, thyroid-stimulating hormone; TSHoma, pituitary adenomas that produce TSH; UFC, urine free cortisol; USP8, ubiquitin carboxyl-terminal hydrolase 8; VEGF, vascular endothelial growth factor; XLAG, X-linked acrogigantism.

\section{Background}

The pituitary gland is responsible for the production and or secretion of various hormones that play a vital role in regulating endocrine function within the body. 
The pituitary gland consists of two lobes an anterior and a posterior lobe [1]. Hormones produced by the anterior lobe of the pituitary gland include growth hormone (GH), thyroid-stimulating hormone (TSH), luteinizing hormone (LH), follicular stimulating hormone (FSH), adrenocorticotrophin (ACTH) and prolactin (PRL). Hormones stored and released from the posterior pituitary are antidiuretic hormone (ADH)/vasopressin and oxytocin. ADH and oxytocin are produced by neurosecretory cells in the hypothalamus [2]. Trophic hormones produced by the hypothalamus stimulate production of different anterior pituitary hormones which in turn stimulate production of hormones at the level of the target organ [3]. In the case of PRL, secretion is primarily controlled by hypothalamic suppression via dopamine or prolactin release inhibiting hormone [3]. Developmental or acquired pituitary signals may also influence pituitary growth and secretion of hormones [4]. The biology and development of secretory tumors of the pituitary is complex and can cause a variety of endocrine related disorders.

Collectively, the prevalence rate of tumors of the pituitary has been reported to be $16.7 \%$. Other analyses examining post mortem or radiological findings estimate prevalence rates to range between $14.4 \%$ and $22.5 \%$ [5]. However, many reports reviewing prevalence rates are based on post-mortem and radiological findings and may not provide a true indication of incidences of clinically apparent tumors. One study performed in Argentina described the standardized incidence ratio of clinically relevant pituitary tumors to be 7.39/100,000/year, which was more common than expected by the authors [6]. Another report from a Swedish study described incidence rates for prolactinomas of 1.6/100,000, acromegaly $0.35 / 100,000$, Cushing disease $0.18 / 100,000$, and TSH-producing adenomas of 0.03/100,000 [7].

In this review, we will examine secretory tumors of the anterior pituitary focussing on the pathogenesis of these tumor and the biochemical aspects of diagnosis and management.

\section{Physiology and biochemistry}

Normal development of the anterior pituitary follows highly specialized precursor stem cell commitment. Somatotrophs account for $50 \%$ of pituitary hormone secreting cells, with lactrotrophs $(10 \%-25 \%)$, gonadotrophs $(10 \%)$, corticotrophs $(10 \%-20 \%)$ and thyrotrophs (10\%) accounting for the rest [8].

\section{Growth hormone}

Somatotrophs are responsible for the secretion of $\mathrm{GH}$, a 191-amino acid single-chain polypeptide [8, 9]. Pit-1/Pou1 F1 and PROP1 are transcription factors that have been reported to play an integral role in the organogenesis of the anterior pituitary and the development of the somatotrophs [10]. The genes responsible for the coding of pituitary human GH, a placental variant and placental lactogen are located on the long arm of chromosome 17. GH exists in various isoforms including $22-\mathrm{kDa}$ form, $20-\mathrm{kDa}$ form, etc. The 22-kDa GH is considered the most relevant isoform in terms of biological activity and constitutes $90 \%$ of GH in the circulation [9]. Physiological actions of GH include mediation of skeletal growth and regulation of carbohydrate, fat and mineral metabolism $[8,11]$. The growth hormone receptor (GHR) belongs to a family of transmembrane receptors that also includes PRL and cytokine receptors. Biological activity following binding of GH to the cell surface receptor is mediated by dimerization with GHR and activation of JAK2-STAT tyrosine kinase signaling pathway $[11,12]$. Many of the peripheral actions of $\mathrm{GH}$ are enabled by insulin-like growth factor 1 (IGF-1) which is produced by the liver under the action of GH. Centrally, regulation of GH secretion is controlled by the hypothalamic hormones. Growth hormone-releasing hormone (GHRH) is responsible for stimulating secretion of $\mathrm{GH}$, whereas the hormone somatostatin inhibits GH secretion. Actions of GHRH include inducing GH gene transcription and thus secretion of GH. GHRH is also responsible for maintaining somatotroph cell function. Other hormones that stimulate $\mathrm{GH}$ secretion include the gut-derived ghrelin which acts at the levels of hypothalamus to promote GHRH secretion. Somatostatin also plays a role in regulating the timing and amplitude of GH secretion from the anterior pituitary [11].

\section{Prolactin}

PRL is a polypeptide hormone synthesized by the lactotroph group of cells of the anterior pituitary [9, 13]. Lactotrophs and somatotrophs share the common somatomammatroph lineage thus the presence of GH/PRL pituitary tumors are frequently reported [14]. There are several isoforms/variants of PRL. The major form of PRL in the pituitary is the 23-kDa form; 14-, 16- and 22-kDa forms also exist. Dimerization and binding to larger molecules such as immunoglobulins results in larger isoforms of PRL $[15,16]$. Although PRL secretion is regulated by the hypothalamus, unlike other anterior pituitary hormones, the hypothalamic influence is predominantly inhibitory via 
the action of dopamine. Stimulation of PRL secretion can be mediated by factors including thyrotropin releasing hormone (TRH) [17]. Other factors that may stimulate PRL secretion include oxytocin, vasoactive intestinal polypeptide, fibroblast growth factor (FGF), endothelial growth factor, hypothalamic prolactin-releasing peptide, galanin, and neurotensin $[15,16]$. PRL receptors belong to the same family of receptors as $\mathrm{GH}$ and actions are mediated by the JAK-STAT signaling pathway [16]. Physiological function of PRL are mostly related to lactation and reproductive functions $[8,15]$.

\section{ACTH}

ACTH is produced by the corticotroph cells in the anterior pituitary $[8,18]$. The primary role of ACTH is related to is stimulatory action on the production and secretion of cortisol by the adrenal glands [19]. It is formed via cleavage of the precursor hormone pro-opiomelanocortin (POMC) by prohormone convertase enzymes $[18,19]$. POMC is encoded by a single gene on chromosome 2 [20]. Corticotrophin-releasing hormone (CRH) secreted from the hypothalamus positively regulates POMC transcription and thus ACTH secretion. ACTH secretion is pulsatile and demonstrates a typical circadian rhythm. There is negative feedback control from cortisol $[18,19]$. Various other hormones and factors influence ACTH secretion, these include inhibitory factors: oxytocin, atrial natriuretic peptide, opiates and stimulatory factors including catecholamines, vasopressin, $\mathrm{GH}$, tumor necrosis factor and interleukins [18]. Both physical and psychological stress play a major role in the secretion of ACTH and cortisol. Other physiological factors such as eating also influence ACTH secretion [21]. The ACTH receptor is located on cells within the adrenal cortex. It is a G-coupled protein receptor known as melanocortin receptor 2. Binding of ACTH to the receptor activates the secondary messenger system resulting in cyclic AMP generation and stimulation of protein kinase-A $[15,18,19]$.

\section{Thyroid-stimulating hormone (TSH)}

TSH is synthesized within the thyrotrophs of the anterior pituitary. TSH is responsible for the growth of the thyroid and stimulating the production and secretion of thyroid hormones [thyroxine (T4) and tri-iodothyronine (T3)]. TSH - releasing hormone (TRH) secreted by the hypothalamus stimulates the secretion of TSH and negative feedback is regulated by serum T4 and T3 secretions [8]. Like
FSH, LH and human chorionic gonadotrophin, TSH is a glycoprotein hormone consisting of an $\alpha$ and $\beta$ subunit, with the latter conferring biological specificity $[8,15]$.

\section{FSH and LH}

FSH and LH are collectively known as the gonadotrophins and are secreted by the gonadotroph cells of the anterior pituitary [22]. FSH and LH are glycoprotein hormones consisting of $\alpha$ and $\beta$ subunit [23]. The hypothalamic hormone gonadotrophin-releasing hormone $(\mathrm{GnRH})$ stimulates the secretion of gonadotrophins $[8,24]$. The GnRH-gonadotrophin system plays a central role in the regulation of reproduction including steroidogenesis, gametogenesis and ovulation [25]. The actions of GnRH on FSH and LH are not identical. Inhibition occurs from negative feedback from target hormone production, inhibin (FSH inhibition), testosterone and estrogen. However, estrogen is also responsible for positive feedback during part of the menstrual cycle and ovulation $[8,15,22]$.

\section{Secretory tumors of the pituitary gland}

Pituitary adenomas are the most common cause of hyperpituitarism $[8,26]$. These are a diverse group of tumors that are generally benign and slow growing but can also be invasive $[1,8]$.

Pituitary adenomas are often classified according to size: microadenomas, $<10 \mathrm{~mm}$; macroadenomas, $\geq 10-39$ $\mathrm{mm}$; giant adenomas, $\geq 40 \mathrm{~mm}$. Further classification will depend on histological and immunochemical properties as well as if the adenoma is functional (secretory) or non-functional (non-secretory) [27, 28]. Classification of pituitary secretory tumors may be further performed by immunocytochemical analyses, in situ messenger RNA (mRNA) detection of cell gene products and most commonly and conveniently by measurement of the trophic and target hormone concentrations $[1,8,28]$.

Excessive ACTH production leads to hypercortisolaemia (Cushing syndrome). The incidence of Cushing syndrome is $0.7-2.4$ cases per million per year. Pituitary adenomas (Cushing disease) accounts for $75 \%-80 \%$ of ACTH-dependent hypercortisolism and 15\%-20\% are secondary to ectopic production of ACTH [8, 29-31]. Ectopic $\mathrm{CRH}$ producing tumors resulting in Cushing disease are rare and account for $<1 \%$ of patients with ACTH-dependent Cushing and result in corticotroph hyperplasia [32]. 
The most common tumors accounting for this increase ectopic CRH production include medullary thyroid carcinoma, pheochromocytoma and prostate cancer [33]. Cushing disease is more common in females with a ratio of around 8:1 to males and generally presents between 20 and 40 years and is the focus of this review $[8,34]$.

Excessive production of $\mathrm{GH}$ in adults results in the condition known as acromegaly. The tumors are usually macroadenomas and can be sparsely or densely granulated [8]. Sparsely granulated somatotroph adenomas are generally larger, occur more commonly in younger female patients, are more proliferative and have a greater propensity for invasion. Furthermore, densely granulated somatotroph adenomas appear to respond better to somatostatin analogue therapy $[35,36]$. Clinical features of acromegaly include skeletal overgrowth of flat bones, for example the mandible, a condition known as prognathism, growth of bones in the feet and hands with resultant increase in shoe and ring size; overgrowth of skin and subcutaneous tissue, increased presence of skin tags; macroglossia; cardiomyopathy; peripheral neuropathy; carpal tunnel syndrome due to compression of median nerve by increased soft tissue growth. Other derangements including features of abnormal glucose tolerance (impaired fasting glucose/impaired glucose tolerance on oral glucose tolerance test) or frank diabetes mellitus as well as hypertension, osteoarthritis and excessive sweating. Additionally, increased serum phosphate levels may be noted [8]. In children, prior to fusion of epiphyseal plates in long bones (e.g. femur, tibia), excessive GH production results in gigantism. Untreated, the condition results in increased morbidity and mortality due to cardiovascular and pulmonary dysfunction $[8,15]$. The incidence of acromegaly is 5 cases per million per year and the prevalence is 60 cases per million. Over $95 \%$ of patients with acromegaly have a GH-secreting pituitary adenoma derived from the somatotroph cell line. In less than 5\% of cases, acromegaly is a result of excessive GHRH secretion from a hypothalamic or neuroendocrine tumor due to somatotroph hyperplasia. Ectopic production of $\mathrm{GH}$ is rare [36-38].

PRL hypersecretion leads to gonadal failure, secondary infertility and galactorrhea [8, 15]. Prolactinomas account for around $40 \%$ of all pituitary tumors and have been reported to be more common in women $[8,39]$. Cosecretion of GH and PRL is relatively common, occurring in $15 \%-25 \%$ of secretory pituitary adenomas [40]. Mixed tumors co-secreting TSH or ACTH may also arise from single cells $[1,8]$.

TSH-producing adenomas known as thyrotropinomas or TSHomas are very rare and result in hyperthyroidism with a goiter. They represent less than $1 \%$ of functioning pituitary adenomas, with the Swedish national registry reporting an incidence rate of 0.15 cases per million inhabitants per year [41]. Gonadotrophin secreting tumors are the rarest and usually present clinically with infertility [8].

Secretory tumors account for approximately twothirds of all anterior pituitary tumors [8, 42]. The distribution of functioning adenomas has been reported as follows: GH 14\%-30\%; PRL 29\%-60\%; ACTH 13\%-25\%; gonadotrophins $13 \%$; and TSH $1 \%$ [27, 43].

Although the incidence of particular secretory tumors of the pituitary may have a predilection for some populations, as a whole, there are no significant differences in the frequency of pituitary adenomas between the two genders [27, 43]. Additionally, they can be diagnosed at any stage of life but are rarely seen in the prepubertal age group. Small nonfunctional tumors are generally silent and are discovered as incidentalomas on imaging for investigation for other disorders. Pituitary carcinomas are extremely rare. Primary pituitary hyperplasia is also uncommon [8, 27]. However, pituitary enlargement as a result of lactotroph hyperplasia is a common physiological feature of pregnancy $[28,44]$. An approximate twofold increase in pituitary gland size occurs during pregnancy. Nodular hyperplasia, which may involve a single cell type, may mimic a functional adenoma. All cell types may be involved but PRL hyperplasia is the most common, as in pregnancy, resulting in PRL levels of around $200 \mu \mathrm{g} / \mathrm{L}[8,27]$.

\section{Molecular pathogenesis}

The etiology of pituitary tumors are likely multifactorial and involve several initiating and promoting factors. Many of these factors may only be induced after cells have been transformed and are thus not true mechanisms of etiology of the tumors. Benign monoclonal pituitary adenomas arise from a specific cell type [1, 28]. Pituitary microadenomas do not regularly evolve to macroadenomas and both may resolve spontaneously. Development of pituitary carcinoma from adenomas occurs in very rare instances [27, 28]. Additionally, adenoma formation generally does not arise from pituitary cell hyperplasia. This behavior highlights the characteristic of "reversible" plasticity of pituitary adenomas [28]. Mutations resulting in activation of oncogenes such as ras and p53 which are commonly seen in non-endocrine neoplasms have generally not been described in pituitary adenomas [28]. When these are present, they are associated with highly invasive pituitary tumors [28]. The role of the hypothalamus 
in pituitary tumorigenesis has been suggested due to the following phenomena: (a) many pituitary adenomas still respond to hypothalamic stimuli, (b) pituitary tumors may resolve spontaneously, (c) success of use of somatostatin and dopamine analogues for tumor shrinkage provides indication of response to hypothalamic stimuli [28, 45-47].

Most pituitary adenomas are sporadic; however, approximately $3 \%-5 \%$ of cases are familial with multiple endocrine neoplasia type 1 (MEN-1) and Carneys complex accounting for the majority of these [8, 48]. The Carney complex (CC) comprises cardiac myxomas, skin pigmentation and tumors of the anterior pituitary and adrenal gland.

The presence of a pituitary adenoma with pancreatic endocrine tumors and parathyroid tumor constitutes the MEN-1 syndrome. The genetic changes seen in MEN-1 syndrome-related pituitary adenomas is uncommon in sporadic adenomas. MEN-1 syndrome has an autosomal dominant inheritance. The MEN1 gene encodes for a nuclear protein known as MENIN, which plays a role in repressing transactivation as well as regulation of transcription, genome stability and cell proliferation $[28,49]$. MEN-1 syndrome is linked to the chromosome germline mutation 11q13. Loss of heterozygosity for 11q13 has been reported to occur in $30 \%$ of sporadic pituitary tumors. It has been proposed that the MEN1 mutation in these sporadic tumors play a role in progression of the tumor but not initiation [28].

Other genetic syndromes associated with pituitary adenomas include pituitary $\mathrm{GH}$ adenomas associated with the CC tumors. $\mathrm{CC}$ is characterized by microadenomas that arise from GH cells. CC is caused by inactivating mutations or large deletions of the protein kinase, cyclic AMPdependent regulatory type $1 \alpha(P R K A R 1 A)$ gene located at 17q22-24, which codes for the regulatory subunit type I $\alpha$ of protein kinase A gene [50,51].

The McCune-Albright syndrome is another genetic endocrine syndrome associated with pituitary adenomas. The syndrome consists of skeletal and skin defects and pituitary lesions. The genetic defect is the activating gsp mutation in the GNAS1 gene on chromosome 20q13.2. This mutation has also been reported in about $30 \%$ of sporadic GH secreting tumors. The gsp mutation is associated with increased transcription of the factor Pit- 1 and increased GH synthesis [52-54]. The relatively newly described familial isolated pituitary adenoma (FIPA) is a genetic condition describing pituitary tumors without other endocrine or other associated abnormalities. These account for around $2 \%$ of pituitary tumors [55].

Around $20 \%$ of FIPA cases have been linked to a germline mutations in the aryl hydrocarbon receptor interacting protein gene and a smaller number are the result of a duplication on the $\mathrm{X}$ chromosome in a condition termed X-linked acrogigantism [55, 56]. FIPA may be associated with any of the anterior pituitary gland tumors both secretory and non-functioning with GH-related tumors being the most commonly associated tumor. These patients present in the second or third decade of life and are more likely to have macroadenomas, with more aggressive tumors that are more likely to be treatment resistant [56].

Deletions in the region of 13q14 have been identified in pituitary adenoma. Amplification of HRAS, CFOS and CMYC genes and inactivation of tumor suppressor genes RB1, TP53 and NM23 have been reported to be involved in pituitary tumor progress [28].

The oncogene pituitary tumor transforming gene $(P T T G)$ has been described in wide range of pituitary adenomas [28]. PTTG has been shown to be overexpressed in pituitary tumors and to correlate with tumor invasiveness [57]. Its exact role in tumor pathogenesis is uncertain; however, it has been associated with FGF to stimulate vascular growth [58]. PTTG has also been identified as belonging to the group of regulatory proteins known as securins which are important in the process of mitosis and regulation of chromosome separation [28].

Other factors described in pituitary tumorigenesis include growth factors such as FGF-B, tumor growth factor-B (TGF-B) and vascular endothelial growth factor. Endocrine trophic factors have also been described as promoting pituitary adenoma formation [59]. Estrogen is mitotic for lactotrophs and gonadotrophs and has been shown to increase TGF-B expression [45]. No mutational events have been unequivocally associated with prolactinomas; however, a significant correlation between estrogen receptor Er $\alpha$ mRNA and PRL level, tumor volume and TGF $\beta 1$ mRNA has been observed in prolactinomas. The pathogenetic mechanisms of TSHomas are not well understood. This may in part be due to the rarity of TSHomas (estimated to represent $1 \%-3 \%$ of pituitary adenomas). No mutations have so far been associated with TSHomas [35]. The recently described ubiquitin carboxylterminal hydrolase 8 (USP8) gene has been reported to be a somatic mutational hotspot that has been found in up to $50 \%$ of corticotrophinomas. Mutations in USP8 lead to a decrease in lysosomal degradation of EGF receptor (EGFR), thereby allowing increased effect of epidermal growth factor due to sustained EGFR cell signaling (an important regulator of corticotroph function) which has increased expression in Cushing disease [38, 60].

The role of epigenetic changes viz. DNA methylation, histone modification and micro RNA (miRNA) have also 
been explored. CpG (cytosine linked to guanine nucleotide by a phosphodiester bond) island methylation, which usually encompass the gene promoter regions play a role in regulating transcription. Inappropriate methylation of $\mathrm{CpG}$ islands is associated with gene silencing. Suppressed expression of $R b, P 16, F G F R 2, G A D D 45 \gamma$ has been shown in pituitary adenomas, particularly the non-functioning kind [49].

miRNAs are small ( $\sim 22$ nucleotides), non-coding RNA molecules which play important roles in cell proliferation, differentiation, and apoptosis. Certain miRNAs such as miR-128, miR-122 and miR26b have been reported to be associated with secretory tumors of the pituitary [48].

\section{Diagnosis of secretory tumors}

Clinical suspicion of secretory pituitary tumors mainly arises with the presence of signs and symptoms related to excessive secretion of the trophic and target hormones. Pituitary adenomas may also present because of local mass symptoms, such as headache, increased intracranial pressure, injury of various cranial nerves and visual disturbances. In particular, with regards to the visual disturbances, the compression of the optic chiasm by the pituitary mass may result in characteristic bitemporal hemianopia.

\section{Clinical biochemistry}

The initial tests should be directed at assaying the hormone whose excess is suspected. Additionally, the possibility of deficiencies of other pituitary hormones should also be considered and relevant testing performed as detailed previously $[8,61]$. Patterns of excessive secretion of hormones are not uniform and may cycle between normal and excessive secretion due to the pulsatile nature of their secretion.

\section{Excessive production of growth hormone}

\section{Growth hormone measurement}

Random GH levels are usually not recommended due to the diurnal and pulsatile nature of secretion that occurs during a day [11]. However, although a randomly elevated
GH level does not imply presence of excessive secretion, it has been reported than random values of less than 0.04 $\mathrm{ng} / \mathrm{L}$ can be utilized to exclude the diagnosis of acromegaly [37]. Dynamic function (suppression) testing forms the cornerstone of laboratory investigations of GH excess.

Oral glucose tolerance test: A hallmark of a GH secretory pituitary tumor is the inability to respond appropriately to a glucose-induced suppressive signal. The oral glucose suppression test involves intake of $75 \mathrm{~g}$ of glucose with measurement of $\mathrm{GH}$ levels at 0 and $120 \mathrm{~min}$. A GH level at $120 \mathrm{~min}$ of $<1 \mu \mathrm{g} / \mathrm{L}$ usually excludes the diagnosis of acromegaly [36]. However, this cut-off has been reported as being less sensitive, with recommendations of lower levels cut-offs $(<0.3 \mu \mathrm{g} / \mathrm{L})$ with more sensitive assays [37]. Rarely, there is a paradoxical increase in GH levels during the OGTT. The GH level following OGTT can be impaired by aging, female gender and obesity [36].

\section{Assay}

Older radioimmunoassays that were previously used for GH measurement have made way for newer immunoassay methods using chemiluminescence as the detection signal as well as utilizing monoclonal antibodies. This has improved the precision of the assays - however, several challenges still beset the measurement of GH. The most significant of which being the lack of standardization of GH among different platforms. The difficulty with standardization of this assay stems from the following core issues: (a) GH is not a homogenous molecule - it occurs in the circulation as homo and heterodimers, consequently use of monoclonal antibodies in assays means that only some isoforms will be recognized and measured. The use of polyclonal antibodies has been proposed to ensure that more than one of the biologically active forms of GH is measured in a sample. (b) Interference caused by GH binding protein (GHBP) [62]. As up to $50 \%$ of $\mathrm{GH}$ in circulation is bound to GHBP, this may affect accessibility of binding sites by antibodies in assays. This is associated with underestimation of GH especially in assays using monoclonal antibodies. A negative interference of up to $50 \%$ has been reported in certain GH immunoassays [63-65]. Also, GHBP concentrations are affected by liver disease, nutritional and metabolic conditions. Several standard preparations for calibration of GH assays have been in use including the first International Standard (IS) 66/217 and the subsequently introduced IS $80 / 505$, both used GH isoforms of pituitary origin. However, the true GH content 
of the pituitary extracts was unknown and an arbitrarily chosen value was assigned. Newer standard materials IS $88 / 624$ and more recently IS $98 / 574$ (current in use standard preparation) used recombinant GH [62]. Recommendations from a joint meeting in 2010 held with the Growth Hormone Research Society in collaboration with the International Federation for Clinical Chemistry and Laboratory Medicine, the International Society for IGF Research and the Pituitary Society were that for GH assays apart from adoption of one defined IS, the isoform specificity of assay antibodies should be known and should ideally only recognize the 22-kDa isoform [65].

The other issue with use of GH assays is the interconversion between SI and conventional units. This has significant impact on clinical decision limits which to date have been used with little regard for assays used for the $\mathrm{GH}$ determination and assay of origin for the cut-point. Current recommendations for GH assay performance is that the assay achieve a lower limit of quantification of $0.05 \mu \mathrm{g} / \mathrm{L}$ with a CV of $<20 \%$ [65].

\section{IGF-1 measurement}

IGF-1 is reflective of integrated cumulative exposure of peripheral tissue to excessive $\mathrm{GH}$ concentrations and, as a mediator of GH is elevated in the presence of increased GH levels. It has been recommended as the initial screening test for GH excess for the following reasons: (a) unlike GH which requires suppression testing and fasting samples, random samples can be used for IGF-1 measurement; (b) IGF-1 is not subject to diurnal, pulsatile variation as with $\mathrm{GH}$ and is not influenced by other pre-analytical factors such as recent meal ingestion, exercise and sleep and has a longer half-life due to its binding proteins $[8,37,66]$. However, there is significant within person biological variation (3\%-36\%) reported for IGF-1 [67]. Other factors including aging, pubertal development, extremes in body mass index, pregnancy, uncontrolled diabetes, malnutrition, hypothyroidism, hepatic and renal diseases affect IGF-1 levels [36]. Since IGF-1 is age and gender dependent (particularly in children and adolescents) it is vital that the appropriate age and gender related reference intervals be utilized when interpreting results. Additionally, reference intervals defined need to be method/assay specific. The mainstay of IGF-1 measurement remains immunoassay platforms. Standardization of IGF-1 remains an issue with poor agreement between different immunoassays [67]. Krebs et al. reported regression slopes of between 0.527 and 1 when five different immunoassays were compared to the former gold standard, the Nichols Advantage assay. Currently, a reference standard IS 02/254 using recombinant material is available [68].

Like GH, IGF-1 also has binding proteins which may affect assays by interfering with antibody binding sites generally resulting in falsely low results. Different methods of removal of the binding proteins also leads to poor between-assay correlations [65]. Recently reports have described the use of LC-MS/MS methods for the determination of IGF-1 [69, 70]. Being a small molecule IGF-1 lends itself to better performance in terms of specificity and accuracy using this methodology. An enrichment step is usually carried out before sample extraction, which would require a step for disassociation of binding proteins from IGF-1 [70].

It is interesting to note that several strides in $\mathrm{GH}$ and IGF-1 measurement have been made because of their use as performance enhancing agents and the efforts of antidoping agencies to detect their illicit use.

About $15 \%$ of patients with acromegaly can have a tumor producing both GH and PRL [8]. Although our focus is on the clinical biochemistry, it is important to emphasize that imaging with magnetic resonance imaging (MRI) is crucial in the diagnosis since the majority of tumors are macroadenomas and can be invasive $[8,42]$. It is prudent to undertake a colonoscopy to rule out the increased risk of colonic neoplasms and sleep studies to rule out obstructive sleep apnoea. Early diagnosis and management of acromegaly is of great importance given the twofold increased mortality largely from cardiovascular causes [42]. Biochemical goals of therapy include IGF-1 levels in the age appropriate reference range and a random GH level $<1 \mu \mathrm{g} / \mathrm{L}$ [42].

\section{Prolactinoma}

Prolactinomas represent at least 50\% of all secretory adenomas of the pituitary and present with galactorrhea and amenorrhea in women and decreased impotence and libido in men (hypogonadism in both men and women) $[8,71]$. PRL levels should be assayed in patients with hypogonadotrophic hypogonadism and males with hypogonadism and infertility. Basal levels of PRL are useful with values of $>100 \mu \mathrm{g} / \mathrm{L}$ generally associated with the presence of a prolactinoma usually a microadenoma and $>200 \mu \mathrm{g} / \mathrm{L}$ due to a macroadenoma. PRL levels generally parallel the tumor size. PRL may be increased due to other causes non-related to presence of a pituitary secreting 
tumor. These include pituitary stalk disease and various medications that inhibit dopamine. Since drug ingestion is a very common cause of elevated PRL levels, a careful history needs to be taken to exclude estrogen therapy, dopamine antagonists (such as metoclopramide, opioids and phenothiazines) and use of monoamine oxidase inhibitors [8]. Physiological conditions such as pregnancy and pathological conditions such as primary hypothyroidism, cirrhosis and chronic kidney disease also result in elevated PRL levels [8, 72]. In most of the above conditions PRL levels rarely exceed $100 \mu \mathrm{g} / \mathrm{L}$.

PRL is routinely measured by immunoassay methods commonly using chemiluminescence or electrochemiluminescence methods. The presence of macroprolactin, a biologically inactive but immunoreactive form of PRL that is bound to immunoglobulin G, results in falsely elevated PRL levels to differing extents in currently available commercial assays. The vast majority of patients with macroprolactinemia are asymptomatic; however, some may have few nonspecific symptoms that may also occur in hyperprolactinemia, thus confounding the clinical differentiation of those with true monomeric increase from those with macroprolactin [73-75]. It is a rare occurrence but laboratorians need to be aware on how to exclude macroprolactinemia. The structure of macroprolactin and its interaction with the different assays are variable [76].

In suspected macroprolactinemia, laboratory procedures for confirming macroprolactin are recommended [77]. It is important that whichever method is used for the detection of macroprolactin, it has been validated for use with the assay platform used to measure PRL. The simplest of these involve precipitation of the macroprolactin component following treatment of the patient sample with a polyethylene glycol solution and then measurement of the PRL in the supernatant of the treated sample [78]. Partial precipitation of certain immunoglobulin groups may occur together with interference in some manufacturer assays [79]. Gel filtration chromatography is the gold standard for measurement of monomeric PRL but is costly, technically demanding and may cause an under or overestimation due to denaturation of adsorption during the gel run [80-87]. Other methods for detection of macroprolactin include ultrafiltration and immune-adsorption, which are also not commonly performed in routine laboratories [82].

An additional issue related to the laboratory measurement of PRL using immunoassay based platforms is the presence of the hook effect. The hook effect results in falsely low or normal results in the presence of true high values of PRL due to the prozone phenomenon [83].
This can be easily overcome by dilution of the specimen $1 / 20$ or $1 / 50$. The hook effect is usually suspected with larger tumors and the clinical syndrome without a commensurate increase in PRL.

\section{Cushing disease: endogenous ACTH excess}

The laboratory investigation of Cushing disease begins with the confirmation of excessive endogenous corticosteroid production followed by identification of ACTHdependent production and determination of site of ACTH production $[84,85]$. An absolute requirement prior to biochemical investigation is to exclude exogenous intake of glucocorticoids [85].

\section{Tests for confirmation of hypercortisolemia}

Confirmation of hypercortisolemia often remains a diagnostic challenge with more than one test for hypercortisolemia usually being required.

(a) Serum or salivary samples may be used to obtain a midnight cortisol level. Cushing syndrome is associated with a loss of circadian rhythm of cortisol production and there is an accompanying loss of the normal nadir of cortisol at midnight. Serum cortisol greater than $(5 \mu \mathrm{g} / \mathrm{dL})$ or salivary cortisol greater than $(0.15 \mu \mathrm{g} / \mathrm{dL})$ is in keeping with a diagnosis of Cushing syndrome $[84,85]$. Sensitivity and specificity $(92 \%-100 \%$ each) of midnight salivary cortisol levels have reported superiority to other screening methods for hypercortisolemia [84]. Utility of salivary cortisol is more convenient for patients as collection may be done at home. Collection is done using devices such as Salivette collection device. Patients need to be instructed appropriately regarding collection of saliva in particular avoiding collection in the presence of mouth ulcers, etc. and avoidance of aggressive tooth brushing prior to collection as contamination with blood will result in a falsely elevated salivary cortisol. Salivary cortisol increases with aging, diabetes and hypertension [85]. However, it appears to be superior to 24-h urine free cortisol (UFC) in confirming a diagnosis of Cushing syndrome. At least two collections should be performed to confirm positive results [85].

(b) 24-h UFC measures unbound (free) cortisol excreted in the urine. 
The assays of choice are either HPLC or tandem MS. Immunoassays are very unreliable due to cross reactivity from other metabolites. The unbound fraction is the active fraction in serum and comprises $2 \%-3 \%$ of the total circulating cortisol [19]. The upper limit of normal for the particular assay used is recommended as the criterion for a positive test, provided the creatinine shows that the collection is complete and the volume is not excessive. Generally, 24-h UFC values above two to 3 times the upper limit of normal are suggestive of hypercortisolemia. It cannot be used in patients with significant renal impairment and has low sensitivity and specificity. False-positive results may be seen with high fluid intake and urine output $>5.0 \mathrm{~L} / 24 \mathrm{~h}$, depression and excessive alcohol intake [84]. When HPLC is used, both fenofibrate and carbamazepine can co-elute resulting in false positives [19]. False negatives can result with chronic kidney disease with a decrease in e-GFR [85]. At least two collections should be performed to confirm findings [85].

(c) Overnight dexamethasone suppression test (ODST): $1 \mathrm{mg}$ of dexamethasone is administered between $11 \mathrm{pm}$ and midnight and the serum cortisol is measured the next morning between 8 and $9 \mathrm{am}$. In normal individuals the cortisol is suppressed below $1.8 \mu \mathrm{g} / \mathrm{dL}$. A morning cortisol value of less than $5 \mu \mathrm{g} / \mathrm{dL}$ has also been previously described as a cut off for adequate suppression. However, current guidelines recommend the $1.8-\mu \mathrm{g} / \mathrm{dL}$ cutpoint as the higher value of $5 \mu \mathrm{g} / \mathrm{dL}$ led to misclassification of up to $15 \%$ of patients with Cushing syndrome as negative [84-86]. Drugs affecting the absorption and metabolism of dexamethasone such as phenytoin and carbamazepine may affect results resulting in false positives.

False positives for the ODST may also occur with obesity, depression, chronic alcoholism and high estrogen states [84]. Failure of patients to take the dexamethasone dose would also result in false positives. Additionally, the wide inter-personal variation in dexamethasone metabolism as well as the effect of a number of commonly used medications on the metabolizing CYP3A4 enzyme complex may result in false positive or negative results [85]. Measurement of serum dexamethasone in any suppression test is useful to assess if adequate levels of drug are present for a valid result [87].

(d) Low dose dexamethasone suppression test (LDDST): In this test, $0.5 \mathrm{mg}$ of dexamethasone is taken orally every $6 \mathrm{~h}$ for $48 \mathrm{~h}$. The initial dose on day 0 is taken at $9 \mathrm{am}$. The serum cortisol is measured between 8 and
9 am at 24 and $48 \mathrm{~h}$ respectively after the start of the test [19]. The same cortisol decision level for ODST is used [84]. The ODST has largely supplanted this test which is far more cumbersome.

(e) In patients with cyclical Cushing or where there is strong clinical suspicion of disease but tests for hypercortisolemia have been negative - the dexamethasone - CRH test has been used. This is based on the theory that a small number of patients with Cushing disease as well as normal individuals will show suppression to dexamethasone, but those with Cushing disease will respond to CRH with a rise in ACTH and cortisol [88]. The procedure for this test involves individuals receiving $0.5 \mathrm{mg}$ dexamethasone orally every $6 \mathrm{~h}$ for eight doses. Blood samples for serum cortisol are taken $2 \mathrm{~h}$ after the last dose of dexamethasone and just before administration of intravenous bolus injection of $100 \mu \mathrm{g}$ CRH. Serum samples for cortisol are taken at 15, 30, 45, and 60 min after CRH. A serum cortisol concentration of $1.8 \mu \mathrm{g} / \mathrm{dL}$ or less after the LDDST and of $<1.4 \mu \mathrm{g} / \mathrm{dL}$ or less $15 \mathrm{~min}$ after CRH injection is considered normal [89].

\section{Determination of ACTH dependence/ independence}

(a) Measurement of ACTH: Increased ACTH levels in the presence of elevated cortisol secretion supports the presence of an ACTH-dependent cause of Cushing syndrome. If ACTH is $>15 \mathrm{pg} / \mathrm{mL}$, it is an ACTH-dependent cause of Cushing syndrome. It has also been noted that patients with ectopic ACTH and CRH secretion usually have higher levels of ACTH than those with Cushing disease [88].

(b) High dose dexamethasone suppression test: This is based on the principle that most pituitary corticotroph tumors do retain some degree of responsiveness to negative glucocorticoid feedback, whereas ectopic ACTH-secreting tumors typically do not. Two milligrams of dexamethasone is administered every $6 \mathrm{~h}$ for $48 \mathrm{~h}$ or with a single dose of $8 \mathrm{mg}$. Eighty percent of patients with Cushing disease will suppress their plasma cortisol to below $50 \%$ of baseline plasma cortisol levels [88].

(c) CRH stimulation test: CRH is produced by the hypothalamus and stimulates production of ACTH by the pituitary $[18,19]$. In this test CRH is administered intravenously and ACTH and cortisol are measured at baseline and at 15, 30 and 45 min thereafter. A rise in ACTH greater than $40 \%$ and cortisol levels greater 
than 20\% indicate an ACTH-dependent cause most likely Cushing disease, as ectopic sources of ACTH are not usually responsive to CRH stimulation [19].

The CRH stimulation test may be accompanied with bilateral inferior petrosal sinus (IPS) sampling to confirm the presence of a pituitary lesion causing Cushing. During this invasive procedure the IPSS into which the pituitary venous blood drains is catheterized by a radiologist. ACTH is measured at baseline and following stimulation with $100 \mu \mathrm{g}$ of CRH from both IPS and peripheral veins. Measurement of PRL is also performed to confirm the catheter is in the correct position. A ratio of IPS to peripheral ACTH of 2:1 before CRH stimulation and 3:1 after stimulation indicates a pituitary cause of ACTH-dependent Cushing syndrome $[88,90]$. False negative results with BIPSS include cyclic or mild Cushing syndrome, tumor with low responsiveness to $\mathrm{CRH}$, ectopic tumor located in sphenoid sinus, false positives are less common. Technique with regards to catheterization and anatomical variants with regards to pituitary venous drainage may also affect performance of test and the testing should be undertaken in centers with expertise in this area [90]. BIPSS sampling is the most definite test in our repertoire to confirm pituitary dependent Cushing disease with a sensitivity and specificity of around 95\% [91].

\section{Assay issues}

Women receiving oral estrogen therapy may have elevated levels of cortisol-binding globulin resulting in high total serum cortisol levels; however, UFC and salivary cortisol which are unbound are not similarly affected [42]. Measurement of salivary cortisol may be performed by adaptation of commercial serum immunoassays or LC-MS/MS methodologies. Analytical sensitivity and adequate performance at the lower linear range of the assay is important for clinical utility of these assays. The presence of cyclical disease may results in normal laboratory findings if samples are taken during the time of normal secretion [92]. Standardization across different platforms for cortisol measurement has been an issue, in particular related to cut-off values that were developed using a specific assay that may not be transferable to another platform. There are currently reported six reference materials for cortisol which results in a lack of transferability across different platforms for cortisol. Although decision limits for Synacthen and dexamethasone suppression tests were developed using immunoassay methods as yet they have not been validated using
LC-MS/MS methods. Immunoassays also show lack of specificity and significant inter-assay differences [93]. El-Farhan et al. reported that for the proficiency testing UK NEQAS scheme the divergence between the different immunoassay participants were so great that a single, meaningful mean to be used as the target could not be calculated. The scheme had decided to use LC-MS/MS values to set the target. Use of LC-MS/MS has improved the specificity and sensitivity of cortisol assays and is the method of choice for salivary cortisol. However, in addition to a lack of validation of cut-offs for cortisol with LC-MS/MS method, there is also the lack of a single, validated reference range [93].

\section{TSH-producing adenoma}

Thyrotropinomas or TSHomas are characterized by a pituitary tumor coupled with increased TSH, T4 and T3 levels [85]. Since glycoprotein hormones have $\alpha$ and $\beta$ subunits, tumors can produce an excess of the $\alpha$ subunit of TSH in thyrotropinomas and an abnormally high $\alpha$ subunit $(\mathrm{ng} / \mathrm{mL})$ to TSH $(\mathrm{mIU} / \mathrm{L})$ molar ratio $(>1)$ will be seen. Other measures of hyperthyroidism that can be useful include elevated levels of sex hormone-binding globulin (SHBG) [94]. Increase in SHBG levels is thought to be an indirect effect of increase thyroid hormones in circulation causing an in increase in hepatocyte nuclear factor $4 \alpha$ levels in hepatocytes which in turn promotes SHBG formation [95]. Patients with TSHoma also have elevated levels of serum carboxy-terminal cross linked telopeptide type 1 collagen (ICTP). This is indicative of the hypermetabolic state of bone in hyperthyroidism.

TRH stimulation test can be used to evaluate patients with suspected TSHomas. Following administration of TRH, TSH is measured. There is a lack of a normal TSH response to TRH in TSHoma [94]. The T3 suppression test has also been used to detect the presence of a TSHoma. After T3 suppression test (80-100 $\mu \mathrm{g} /$ day for 8-10 days) the inhibition of TSH seen in normal individuals will not be observed with TSHoma. However, this test should not be done if there is concomitant cardiovascular or pulmonary diseases [96]. Most TSHomas retain responsiveness to somatostatin and T4 and T3 levels fall following administration. This can also be used to assess if somatostatin analogues will be an effective treatment [97].

In the presence of elevated TSH and normal/high thyroid hormonelevels it is important to exclude a potential analytical interference, poor compliance in a patient with known hypothyroidism and thyroid hormone resistance 
(THR). THR, in particular with the pituitary or central resistant form, present with clinical features of hyperthyroidism and elevated TSH levels similar to TSHomas. The presence of a pituitary adenoma on imaging, together with features of concomitant hypersecretion of other anterior pituitary hormones will aid in confirming the diagnosis TSHoma. Patients with THR often have a family history of this disorder and lack the elevated $\alpha$ subunit, SHBG and ITCP levels found in TSHomas. Familial TSHoma is rare. Additionally findings on TRH stimulation are normal or exaggerated TSH responses and suppression of TSH with T3 with THR [98]. Patients with THR have normal ICTP levels. Administration of somatostatin reduces serum TSH levels in TSHoma but not in THR [96-98]. Since the differentiation of THR from TSHoma can be challenging, all of the above tests can prove helpful.

\section{Gonadotrophin secreting adenomas}

These tumors are usually macroadenomas and can cause visual impairment. Usually, the patients have hypogonadism with elevated FSH and $\alpha$ subunit levels and MRI confirms the tumor [8].

\section{Imaging studies}

Pituitary imaging studies using unenhanced or contrast enhanced MRI are preferred to computed tomography scans for visualization of pituitary adenomas [42, 99]. Often pituitary adenomas are discovered incidentally when imaging studies have been done for other reasons. Formal visual fields need to undertaken when there is a

Table 1: Diagnosis of secretory pituitary tumors.

\begin{tabular}{|c|c|c|}
\hline Hormone overproduction & Test & Interpretation \\
\hline \multirow[t]{2}{*}{ Growth hormone } & IGF-1 measurement (screening) & Increased (age and sex matched reference range) \\
\hline & Oral glucose tolerance test & Failure of $\mathrm{GH}$ to suppress $<1.0 \mu \mathrm{g} / \mathrm{L}$ at $120 \mathrm{~min}$ \\
\hline \multirow[t]{2}{*}{ Prolactin } & Basal prolactin levels & Prolactin between 100 and $200 \mathrm{ng} / \mathrm{mL}$ \\
\hline & $\begin{array}{l}\text { Exclude macroprolactinemia by any of the following } \\
\text { methods: Polyethylene glycol (PEG) precipitation, gel } \\
\text { filtration chromatography, ultrafiltration, immunoadsorption } \\
\text { *Beware of Hook Effect with normal PRL especially with } \\
\text { macroadenoma }\end{array}$ & \\
\hline \multirow[t]{9}{*}{ ACTH (Cushing disease) } & 1) Confirmation of hypercortisolemia & \\
\hline & $\begin{array}{l}\text { - Cortisol values at midnight: Serum or salivary (at least } \\
2 \text { measurements) }\end{array}$ & $\begin{array}{l}\text { Serum }>5 \mu \mathrm{g} / \mathrm{dL} \text { or salivary }>0.15 \mu \mathrm{g} / \mathrm{dL} \\
\text { Salivary cortisol is preferred since it is more } \\
\text { convenient }\end{array}$ \\
\hline & - 24-h urine free cortisol: at least two measurements & $\begin{array}{l}\text { Exceeds the reference range for HPLC or MS/MS } \\
\text { (usually two to three time upper limit of normal) }\end{array}$ \\
\hline & - Overnight dexamethasone suppression test & Failure to suppress $<1.8 \mu \mathrm{g} / \mathrm{dL}$ \\
\hline & - Dexamethasone-CRH test & $\begin{array}{l}\text { Serum Cortisol }>1.4 \mu \mathrm{g} / \mathrm{dL} \text { after } \mathrm{CRH} \text { support } \\
\text { Cushings }\end{array}$ \\
\hline & $\begin{array}{l}\text { 2) Determination of ACTH dependence } \\
- \text { ACTH levels }\end{array}$ & $\begin{array}{l}\text { ACTH }>15 \mathrm{ng} / \mathrm{L} \text { indicative of ACTH-dependent } \\
\text { cause of Cushing syndrome }\end{array}$ \\
\hline & - High dose dexamethasone suppression test & $\begin{array}{l}\text { Cushing disease: suppress to }<50 \% \text { of baseline } \\
\text { cortisol ( } 80 \% \text { of patients), ectopic ACTH- } \\
\text { secreting tumors do not suppress }\end{array}$ \\
\hline & - CRH stimulation test & $\begin{array}{l}\text { Cushing disease: rise in ACTH }>40 \% \text { and cortisol } \\
>20 \% \text { from baseline }\end{array}$ \\
\hline & - CRH stimulation test + BIPSS & $\begin{array}{l}\text { Cushing disease: ratio of IPS:peripheral ACTH } \\
\text { of } 2: 1 \text { before CRH stimulation and 3:1 after } \\
\text { stimulation }\end{array}$ \\
\hline \multirow[t]{5}{*}{ TSH } & TFT & $\begin{array}{l}\text { Raised FT4 and TT3, inappropriately normal or } \\
\text { raised TSH }\end{array}$ \\
\hline & SHBG and ICTP & Raised \\
\hline & $\alpha$ subunit $(\mathrm{ng} / \mathrm{mL})$ to $\mathrm{TSH}(\mathrm{mlU} / \mathrm{L})$ molar ratio & TSHoma: raised $(>1)$ \\
\hline & TRH stimulation test & Impaired TSH response to TRH \\
\hline & T3 suppression test & TSHoma: failure of suppression of TSH \\
\hline Gonadotrophin adenoma & FSH and $\alpha$ subunit & Both raised \\
\hline
\end{tabular}


macroadenoma given the proximity of the optic chiasma to the tumor. Diagnostic tests utilized in the diagnosis of anterior pituitary secretory tumors are summarized in Table 1.

\section{Management}

Management of hyperpituitarism will depend on the cause and the hormone/s effected. For both acromegaly and Cushing disease surgical removal of the adenoma is the treatment of choice. Pharmacological treatment includes the use of somatostatin analogs (e.g. octreotide, lantreotide) can be effective adjunctive for acromegaly, Cushing and TSHoma. Also, competitive GHR antagonists can be useful in acromegaly. For prolactinoma, medical treatment with dopamine agonists is the preferred choice [42].

Surgical management: Apart from prolactinoma, for most pituitary tumors, surgery is the first-line treatment [42]. Resection of pituitary tumors is technically challenging because of the anatomical location. Minimally invasive procedures (trans-sphenoidal surgery) are being increasingly utilized.

Conventional radiotherapy may be used to reduce tumor size; however, pituitary damage and resultant hypopituitarism may result. Stereotactic radiotherapy has been associated with fewer adverse effects that conventional radiotherapy although the risk of hypopituitarism is similar for both [99]. Irradiation is the adjunct therapy used for patients who do not achieve adequate reduction in tumor size, hormone levels, or both in response to surgery, medical therapy, or both [42].

\section{Conclusions}

In this review, we have updated and summarized the physiology and biochemistry of pituitary hormones and the pathogenesis of the secretory tumors. However, our major focus was to update laboratorians especially $\mathrm{PhD}$ clinical chemists and trainees on how to confirm the diagnosis of the different secretory tumors.

Author contributions: All the authors have accepted responsibility for the entire content of this submitted manuscript and approved submission.

Research funding: None declared. Employment or leadership: None declared. Honorarium: None declared.
Competing interests: The funding organization(s) played no role in the study design; in the collection, analysis, and interpretation of data; in the writing of the report; or in the decision to submit the report for publication.

\section{References}

1. Larkin S, Ansorge O. Development and microscopic anatomy of the pituitary gland [Updated 15 Feb 2017]. In: De Groot LJ, Chrousos G, Dungan K, Feingold KR, Grossman A, Hershman JM, et al., editors. Endotext [Internet]. South Dartmouth, MA: MDText.com, Inc., 2000. Available at: https://www.ncbi.nlm.nih.gov/books/ NBK425703/.

2. Nakane PK. Classifications of anterior pituitary cell types with immunoenzyme histochemistry. J Histochem Cytochem 1970;18:9-20.

3. Lechan RM, Toni R. Functional anatomy of the hypothalamus and pituitary [Updated 28 Nov 2016]. In: De Groot LJ, Chrousos G, Dungan K, Feingold KR, Grossman A, Hershman JM, et al., editors. Endotext [Internet]. South Dartmouth, MA: MDText.com, Inc., 2000. Available at: https://www.ncbi.nlm.nih.gov/books/ NBK279126/.

4. Davis S, Ellsworth B, Millan M, Gergics P, Schade V, Foyouzi N, et al. Pituitary gland development and disease: from stem cell to hormone production. Curr Top Dev Biol 2013;106:1-47.

5. Ezzat S, Asa SL, Couldwell WT, Barr CE, Dodge WE, Vance $\mathrm{ML}$, et al. The prevalence of pituitary adenomas. Cancer 2004;101:613-9.

6. Day PF, Loto MG, Glerean M, Picasso MF, Lovazzano S, Giunta $\mathrm{DH}$. Incidence and prevalence of clinically relevant pituitary adenomas: retrospective cohort study in a Health Management Organization in Buenos Aires, Argentina. Arch Endocrinol Metab 2016;60:554-61.

7. Tjornstrand A, Gunnarsson K, Evert M, Holmberg E, Ragnarsson $\mathrm{O}$, Rosen $\mathrm{T}$, et al. The incidence rate of pituitary adenomas in western Sweden for the period 2001-2011. Eur J Endocrinol 2014;171:519-26.

8. Javorsky BR, Aron DC, Findling JW, Tyrell JB. Hypothalamus and the pituitary gland. In: Gardner DG, Shoback D, editors. Greenspan's basic and clinical endocrinology, 10th ed. New York: McGraw-Hill Publishers, 2018:69-118.

9. Herrington J, Carter-Su C. Signaling pathways activated by the growth hormone receptor. Trends Endocrinol Metab 2001;12:252.

10. Mortensen AH, MacDonald JW, Ghosh D, Camper SA. Candidate genes for panhypopituitarism identified by gene expression profiling. Physiol Genomics 2011;43:1105-16.

11. Gunawardane K, Hansen T, Muller N, Christiansen J, Jorgensen JO. Normal physiology of growth hormone in adults [Update: 12 Nov 2015]. In: De Groot LJ, Chrousos G, Dungan K, Feingold KR, Grossman A, Hershman JM, et al., editors. Endotext [Internet]. South Dartmouth, MA: MDText.com, Inc., 2000. Available at: https://www.ncbi.nlm.nih.gov/books/NBK279056/.

12. Lanning NJ, Carter-Su C. Recent advances in growth hormone signaling. Rev Endocr Metab Disord 2006;7:225-35.

13. Goffi V, Binart N, Touraine P, Kelly PA. Prolactin: the new biology of an old hormone. Annu Rev Physiol 2002;64:47-67. 
14. Lania AG, Ferrero S, Pivonello R, Mantovani G, Peverelli E, Di Samo A, et al. Evolution of an aggressive prolactinoma into a growth hormone secreting pituitary tumor coincident with GNAS gene mutation. J Clin Endocrinol Metab 2010;95:13-7.

15. Winter WE, Jialal I, Vance ML, Bertholf RL. Pituitary function and pathophysiology. In: Burtis CA, Ashwood ER, Bruns DE, editors. Tietz textbook of clinical chemistry and molecular diagnostics. St. Louis, MI: Elsevier, 2012:1803-45.

16. Freeman ME, Kanyicska B, Lerant A, Nagy G. Prolactin: structure, function, and regulation of secretion. Physiol Rev 2000;80:1523-631.

17. Dussault JH. The effect of dexamethasone on TSH and prolactin secretion after TRH stimulation. Can Med Assoc J 1974;111:1195-7.

18. Lim CT, Khoo B. Normal physiology of ACTH and GH release in the hypothalamus and anterior pituitary in man [Updated 24 Oct 2017]. In: De Groot LJ, Chrousos G, Dungan K, Feingold KR, Grossman A, Hershman JM, et al., editors. Endotext [Internet]. South Dartmouth, MA: MDText.com, Inc., 2000. Available at: https://www.ncbi.nlm.nih.gov/books/NBK279116.

19. Bertholf RL, Jialal I, Winter WE. The adrenal cortex. In: Burtis CA, Ashwood ER, Bruns DE, editors. Tietz textbook of clinical chemistry and molecular diagnostics. St. Louis, MI: Elsevier, 2012:1847-904.

20. Drouin J. 60 Years of POMC: transcriptional and epigenetic regulation of POMC gene expression. J Mol Endocrinol 2016;56:T99-112.

21. Plotsky PM, Bruhn TO, Vale W. Hypophysiotropic regulation of adrenocorticotropin secretion in response to insulin-induced hypoglycemia. Endocrinology 1985;117:323-9.

22. Thackray VG, Mellon PL, Cross D. Hormones in synergy: regulation of the pituitary gonadotropin genes. Mol Cell Endocrinol 2010;314:192-9.

23. Pierce JG, Parsons TF. Glycoprotein hormones: structure and function. Annu Rev Biochem 1981;50:465-95.

24. Seeburg PH, Mason AJ, Stewart TA, Nikolics K. The mammalian $\mathrm{GnRH}$ gene and its pivotal role in reproduction. Recent Prog Horm Res 1987;43:69-98.

25. Burns KH, Matzuk MM. Minireview: genetic models for the study of gonadotropin actions. Endocrinology 2002;148:2823-35.

26. Gounden V, Jialal I. Hyperpituitarism [Updated 26 Jan 2018]. In: StatPearls [Internet]. Treasure Island, FL: StatPearls Publishing, 2018. Available at: https://www.ncbi.nlm.nih.gov/books/ NBK482233.

27. Ironside JW. Pituitary gland pathology. J Clin Pathol 2003;56:561-8.

28. Melmed S. Mechanisms for pituitary tumorigenesis: the plastic pituitary. J Clin Invest 2003;112:1603-18.

29. Newell-Price J, Bertagna X, Grossman AB, Nieman LK. Cushings syndrome. Lancet 2006;367:1605-17.

30. Hopkins RL, Leinung MC. Exogenous Cushings syndrome and glucocorticoid withdrawal. Endocrinol Metab Clin N Am 2005;34:371-84.

31. Lindholm J, Juul S, Jørgenson J0, Astrup J, Bierre P, FeldtRasmussen $\mathrm{U}$, et al. Incidence and late prognosis of Cushings syndrome: a population-based study. J Clin Endocrinol Metab 2001;86:117-23.

32. Machado MC, Fragaso MC, Moreira AC, Boguszewski CL, Neto LV, Naves LA. Recommendations of the Neuroendocrinology Depart- ment of the Brazilian Society of Endocrinology and Metabolism for the diagnosis of Cushings disease in Brazil. Arch Endocrinol Metab 2016;60:267-86.

33. Shahani S, Nudelman RJ, Nalini R, Kim HS, Samson SL. Ectopic corticotrophin-releasing hormone (CRH) syndrome from metastatic small cell carcinoma: a case report and review of the literature. Diagn Pathol 2010;5:56.

34. Sharma S, Nieman LK, Feelders RA. Cushings syndrome: epidemiology and developments in disease management. Clin Epidemiol 2015;7:281-93.

35. Larkin S, Ansorge O. Pathology and pathogenesis of pituitary adenomas and other sellar lesions [Updated 15 Feb 2017]. In: De Groot LJ, Chrousos G, Dungan K, Feingold KR, Grossman A, Hershman JM, et al., editors. Endotext [Internet]. South Dartmouth, MA: MDText.com, Inc., 2000. Available at: https://www.ncbi. nlm.nih.gov/books/NBK425704/.

36. Katznelson L, Laws ER Jr, Melmed S, Molitch ME, Murad MH, Utz A, et al. Acromegaly: an Endocrine Society Clinical Practice guideline. J Clin Endocrinol Metab 2014;99:3933-51.

37. Melmed S. Acromegaly pathogenesis and treatment. J Clin Invest 2009;119:3189-202.

38. Theodoropoulou M, Reincke M, Fassnacht M, Komada M. Decoding the genetic basis of Cushings disease: USP8 in the spotlight. Eur J Endocrinol 2015;173:M73-83.

39. Fernadez A, Karavitaki N, Wass JA. Prevalence of pituitary adenomas: a community-based, cross-sectional study in Banbury (Oxfordshire, UK). Clin Endocrinol 2010;72:377-82.

40. Melmed S. Medical progress: acromegaly. N Engl J Med 2006;355:2558-73.

41. Ónnestam L, Berinder K, Burman P, Dahlqvist P, Engsrom BE, Wahlberg J, et al. National incidence and prevalence of TSHsecreting pituitary adenomas in Sweden. J Clin Endocrinol Metab 2013;98:626-35.

42. Molitch ME. Diagnosis and treatment of pituitary adenomas: a review. J Am Med Assoc 2017;317:516-24.

43. Jane JA Jr, Laws ER Jr. Surgical treatment of pituitary adenomas [Updated 5 Dec 2016]. In: De Groot LJ, Chrousos G, Dungan K, Feingold KR, Grossman A, Hershman JM, et al., editors. Endotext [Internet]. South Dartmouth, MA: MDText.com, Inc., 2000. Available at: https://www.ncbi.nlm.nih.gov/books/NBK278983/.

44. Karaca Z, Tanriverdi F, Unluhizarci K, Kelestimur F. Pregnancy and pituitary disorders. Eur J Endocrinol 2010;162:453-75.

45. Jeffcoate WJ, Pound N, Sturrock ND, Lambourne J. Longterm follow-up of patients with hyperprolactinaemia. Clin Endocrinol 1996;45:299-303.

46. Bevan JS, Atkin SL, Atkinson AB, Bouloux PM, Hanna F, James RA, et al. Primary medical therapy for acromegaly: an open, prospective, multicenter study of the effects of subcutaneous and intramuscular slow-release octreotide on growth hormone, insulin-like growth factor-I, and tumor size. J Clin Endocrinol Metab 2002;87:4554-63.

47. Corsello SM, Ubertini G, Altomare M, Lovicu RM, Migneco MG, Rota CA, et al. Giant prolactinoma prolactinoma prolactinomas in men: efficacy of cabergoline treatment. Clin Endocrinol 2003;58:662-70.

48. Fukuoka H, TakaHasHi Y. The role of genetic and epigenetic changes in pituitary tumorigenesis. Neurol Med Chir 2014;54:943-57.

49. Tichomirowa MA, Daly AF, Beckers A. Familial pituitary adenomas. J Intern Med 2009;266:5-18. 
50. Kirschner LS, Carney JA, Pack SD, Taymans SE, Giatzakis C, Cho YS, et al. Mutations of the gene encoding the protein kinase A type I-alpha regulatory subunit in patients with the Carney complex. Nat Genet 2000;26:89-92.

51. Correa R, Salpea P, Stratakis C. Carney complex: an update. Eur J Endocrinol 2015;173:M85-97.

52. Weinstein LS, Shenker A, Geiman PV, Merino MJ, Friedman E, Spiegel AM. Activating mutations of the stimulatory $G$ protein in the McCune-Albright syndrome. N Engl J Med 1991;325:1688-95.

53. Vallar L, Spada A, Giannattasio G. Altered Gs and adenylate cyclase activity in human GH-secreting pituitary adenomas. Nature 1987;330:566-8.

54. Bertherat J, Chanson P, Montminy M. The cyclic adenosine $3^{\prime}, 5^{\prime}$-monophosphate-responsive factor CREB is constitutively activated in human somatotroph adenomas. Mol Endocrinol 1995;9:777-83.

55. Beckers A, Aaltonen LA, Daly AF, Karhu A. Familial isolated pituitary adenomas (FIPA) and the pituitary adenoma predisposition due to mutations in the aryl hydrocarbon receptor interacting protein (AIP) gene. Endocr Rev 2013;34:239-77.

56. Stiles CE, Korbonits M. Familial isolated pituitary adenoma [Updated 11 Nov 2016]. In: De Groot LJ, Chrousos G, Dungan K, Feingold KR, Grossman A, Hershman JM, et al., editors. Endotext [Internet]. South Dartmouth, MA: MDText.com, Inc., 2000. Available at: https://www.ncbi.nlm.nih.gov/books/ NBK278949/.

57. Pei L. Activation of mitogen-activated protein kinase cascade regulates pituitary tumor-transforming gene transactivation function. J Biol Chem 2000;275:31191-8.

58. McCabe CJ, Khaira JS, Boelaert K, Heaney AP, Tannahill LA, Hussain $S$, et al. Expression of pituitary tumor transforming gene (PTTG) and fibroblast growth factor-2 (FGF-2) in human pituitary adenomas: relationships to clinical tumor behaviour. Clin Endocrinol 2003;58:141-50.

59. Heaney AP. Pituitary tumor pathogenesis. Br Med Bull 2005;75:81-97.

60. Reincke M, Sbiera S, Hayakawa A, Theodoropoulou M, Osswald $A$, Beuschlein $F$, et al. Mutations in the deubiquitinase gene USP8 cause Cushings disease. Nat Genet 2015;47:31-8.

61. Gounden V, Jialal I. Hypopituitarism (Panhypopituitarism) [Updated 16 Nov 2017]. In: StatPearls [Internet]. Treasure Island, FL: StatPearls Publishing, 2018. Available at: https://www.ncbi. nlm.nih.gov/books/NBK470414/.

62. Bidlingmaier M. Problems with growth hormone assays and strategies towards standardization. Eur J Endocrinol 2008;159:S41-4.

63. Jansson C, Boguszewski C, Rosberg S, Carlsson L, AlbertssonWikland K. Growth hormone (GH) assays: influence of standard preparations, GH isoforms, assay characteristics, and GH-binding protein. Clin Chem 1997;43:950-6.

64. Hansen TK, Fisker S, Hansen B, Sorensen HH, Christiansen JS, Jorgensen JO, et al. Impact of GHBP interference on estimates of GH and GH pharmacokinetics. Clin Endocrinol 2002;57:779-86.

65. Clemmons DR. Consensus statement on the standardization and evaluation of growth hormone and insulin-like grow factor assays. Clin Chem 2011;57:555-559.
66. Frystyk J, Freda P, Clemmons DR. The current status of IGF-I assays - a 2009 update. Growth Horm IGF Res 2009;20:8-18.

67. Milani D, Carmichael JD, Welkowitz J, Ferris S, Reitz RE, Danoff A, et al. Variability and reliability of single serum IGF-I measurements: impact on determining predictability of risk ratios in disease development. J Clin Endocrinol Metab 2004;89:2271-4.

68. Krebs A, Wallaschofski H, Spilcke-Liss E, Kohlmann T. Five commercially available insulin-like growth factor I (IGF-I) assays in comparison to the former nichols advantage IGF-I in a growth hormone treated population. Clin Chem Lab Med 2008;46:1776-83.

69. Kam RK, Chung SH, Michael HM. Serum insulin-like growth factor I quantitation by mass spectrometry: insights for protein quantitation with this technology. EJIFCC 2016;27:318-30.

70. Cox H, Lopes F, Woldermariam G, Becker J, Parkin MC, Thomas $A$, et al. Interlaboratory agreement of insulin-like growth factor 1 concentrations measured by mass spectrometry. Clin Chem 2014;60:541-8.

71. Chanson P, Maiter D. Prolactinoma. In: Melmed S, editor. The pituitary. Los Angeles, CA: Academic Press, 2017:467-514. DOI:10.1016/B978-0-12-804169-7.00016-7.

72. Glezer A, Bronstein M. Hyperprolactinemia [Updated 27 Mar 2014]. In: De Groot LJ, Chrousos G, Dungan K, Feingold KR, Grossman A, Hershman JM, et al., editors. Endotext [Internet]. South Dartmouth, MA: MDText.com, Inc., 2000. Available at: https://www.ncbi.nlm.nih.gov/books/NBK278984/.

73. Lippi G, Plebani M. Macroprolactin: searching for a needle in a haystack? Clin Chem Lab Med 2016;54:519-22.

74. Kavanagh L, McKenna J, Fahie-Wilson M, Gibney J, Smith TP. Specificity and clinical utility of methods for the detection of macroprolactin. Clin Chem 2006;52:1366-72.

75. Fahie-Wilson MN, John R, Ellis AR. Macroprolactin; high molecular mass forms of circulating prolactin. Ann Clin Biochem 2005;42:175-92.

76. McCudden CR, Sharpless JL, Grenache DG. Comparison of multiple methods for identification of hyperprolactinemia in the presence of macroprolactin. Clin Chim Acta 2010;411:155-60.

77. Suliman AM, Smith TP, Gibney J, McKenna TJ. Frequent misdiagnosis and mismanagement of hyperprolactinemic patients before the introduction of macroprolactin screening: application of a new strict laboratory definition of macroprolactinemia. Clin Chem 2003;49:1504-9.

78. Atha DH, Ingham KC. Mechanism of precipitation of proteins by polyethylene glycols. J Biol Chem 1981;256:12108-17.

79. Fahie-Wilson M, Halsall D. Polyethylene glycol precipitation: proceed with care. Ann Clin Biochem 2008;45:233-5.

80. Vaishya R, Gupta R, Arora S. Macroprolactin; a frequent cause of misdiagnosed hyperprolactinemia in clinical practice. J Reprod Infertil 2010;11:161-7.

81. Hattori N, Nakayama Y, Kitagawa K, Ishihara T, Saiki Y, Inagaki C. Anti-prolactin (PRL) autoantibody binding sites (epitopes) on PRL molecule in macroprolactinemia. J Endocrinol 2006;190:287-93.

82. Kasum M, Oreskovic S, Zec I, Jezek D. Macroprolactinemia: new insights in hyperprolactinemia. Biochem Med (Zagreb) 2012;22:171-9. 
83. Agarwal M, Das A, Singh AS. High-dose hook effect in prolactin macroadenomas: a diagnostic concern. J Hum Reprod Sci 2010;3:160-1.

84. Nieman LK, Biller BM, Findling JW, Newell-Price J, Savage MO, Stewart PM, et al. The diagnosis of Cushing syndrome. J Clin Endocrinol Metab 2008;93:1526-40.

85. Nieman LK. Cushings syndrome: update on signs, symptoms and biochemical screening. Eur J Endocrinol 2015;173:m33-8.

86. Nieman LK, Biller BM, Findling JW, Murad MH, Newell-Price J, Savage M, et al. Treatment of Cushings syndrome: an Endocrine Society Clinical Practice guideline. J Clin Endocrinol Metab 2015;8:2807-31.

87. Meikle AW. Dexamethasone suppression tests: usefulness of simultaneous measurement of plasma cortisol and dexamethasone. Clin Endocrinol 1982;16:401-8.

88. Juszczak A, Sulentic P, Grossman A. Cushings syndrome [Updated 17 Jul 2017]. In: De Groot LJ, Chrousos G, Dungan K, Feingold KR, Grossman A, Hershman JM, et al., editors. Endotext [Internet]. South Dartmouth, MA: MDText.com, Inc., 2000. Available at: https://www.ncbi.nlm.nih.gov/books/NBK279088/.

89. Yanovski JA, Cutler GB Jr, Chrousos GP, Nieman LK. Corticotropin-releasing hormone stimulation following low dose dexamethasone administration. A new test to distinguish Cushings syndrome from pseudo-Cushings states. J Am Med Assoc 1993;269:2232-8.

90. Zampetti B, Grossrubatscher E, Ciaramella PD, Boccardi E, Loli P. Bilateral inferior petrosal sinus sampling. Endocr Connect 2016;5:R12-25.

91. Lacroix A, Feelders RA, Stratakis CA, Nieman LK. Cushings syndrome. Lancet 2015;386:913-27.
92. Velez DA, Mayberg MR, Ludlam WH. Cyclic Cushing syndrome: definitions and treatment implications. Neurosurg Focus 2007;23:1-3.

93. El-Farhan N, Rees D, Evans C. Measuring cortisol in serum, urine and saliva - are our assays good enough? Ann Clin Biochem 2017;54:308-22.

94. Tritos A. Thyrotropin-secreting pituitary adenomas: pitfalls in diagnosis and management. Neuroendocr Clin Centr Bull Spring/Summer 2011;18. Available at: https://pituitary.mgh. harvard.edu/docs/NCBV2011.pdf. Accessed: 4 April 2018.

95. Selva DM, Hammond GL. Thyroid hormones act indirectly to increase sex hormone-binding globulin production by liver

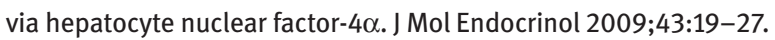

96. Tjornstrand A, Nystrom HF. Diagnosis of endocrine disease. Diagnostic approach to TSH producing pituitary adenoma. Eur J Endocrinol 2017;177:R183-97.

97. Beck-Peccoz P, Brucker-Davis F, Persani L, Smallridge RC, Weintraub BD. Thyrotropin-secreting pituitary tumors. Endocr Rev 1996;17:610-38.

98. Beck-Peccoz P, Persani L, Lania A. Thyrotropin-secreting pituitary adenomas [Updated 1 May 2015]. In: De Groot LJ, Chrousos G, Dungan K, Feingold KR, Grossman A, Hershman JM, et al., editors. Endotext [Internet]. South Dartmouth, MA: MDText.com, Inc., 2000. Available at: https://www.ncbi.nlm.nih.gov/books/ NBK278978/.

99. Evanson J. Radiology of the pituitary [Updated 5 May 2016]. In: De Groot LJ, Chrousos G, Dungan K, Feingold KR, Grossman A, Hershman JM, et al., editors. Endotext [Internet]. South Dartmouth, MA: MDText.com, Inc., 2000. Available at: https://www. ncbi.nlm.nih.gov/books/NBK279161. 